ELORE (ISSN 1456-3010), vol. $14-1 / 2007$.

Julkaisija: Suomen Kansantietouden Tutkijain Seura ry.

[http://www.elore.fi/arkisto/1_07/luk1_07.pdf]

\title{
KiRJA-ARVIO:
}

\section{KULTTUURISIA KUVIA SAAMELAISISTA}

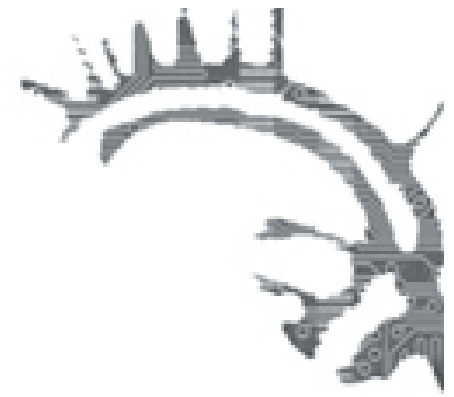

JA SAAMELAISUUDESTA

Kulonen, Ulla-Maija \& Seurujärvi-Kari, Irja \& Pulkkinen, Risto (eds.) 2005: The Saami. A Cultural Encyclopaedia. Suomalaisen Kirjallisuuden Seuran Toimituksia 925. Helsinki: Suomalaisen Kirjallisuuden Seura. 498 sivua.

\section{$\underline{\text { Karina Lukin }}$}

Lueskeltuani ja selailtuani helsinkiläisten saamentutkijoiden toimittamaa kulttuuriensyklopediaa muutaman hetken ymmärsin, miten mahdotonta teoksen kokonaisvaltainen arvioiminen on. The Saami. A Cultural Encyclopaedia sisältää kirjallisuus-, henkilö- ja paikannimihakemistojen lisäksi reilun 400 kaksipalstaisen sivun verran artikkeleja, jotka käsittelevät saamelaisten kulttuurin lisäksi sen tutkimusta, tutkimushistoriaa, saamelaiskieliä, kulttuuripolitiikkaa, saamelaisalueen historiaa ja luontoa. Kirjan tekijät ovat ymmärtäneet kulttuurin aidosti sen laajimmassa ja moninaisimmassa mahdollisessa merkityksessä. Tässä arviossa en voikaan ensyklopedian yleiskuvan välittämisen lisäksi varsinaisesti arvioida muuta kuin teoksen perinteentutkimuksellisia sisältöjä.

\section{Pohjoismaiden laAjuinen Yleiskuva}

Ehdottomasti hedelmällisimmin ja laajimmin kulttuurisanakirja esittelee saamelaisiin ja saamelaisuuteen liittyviä henkilöitä ja näihin liittyvää tutkimushistoriaa tai kulttuuripolitiikkaa. Kirjan viimeisten sivujen henkilöhakemisto lisää edelleen teoksen arvoa tässä mielessä. Niin saamelaisten varhaisemmat tutkijat, tutkimushistoriaan liittyvät henkilöt - lähinnä kulttuurikuvauksia tuottaneet papit - saamelaistaiteilijat, -aktivistit ja -poliitikotkin on laajasti tuotu esiin kirjassa. Tutkimushistorian kannalta kiinnitin erityisesti huomiota kirjoittajien näkemykseen lappologiasta. Saamentutkimushan haluaa nykyään voimakkaasti erottautua vanhasta lappologian perinteestä, jota ensyklopediassakin kuvataan ennakkoluulojen vesittämäksi evolutionistis-romanttiseksi eksoottisen ihmisen etsinnäksi. Muutamaa poikkeusta lukuun ottamatta lappologian katsotaan kestäneen aina 1960-luvulle asti (s. 189-191). Saamentutkimusta tulisi taas harjoittaa 
saamelaiskulttuurin vaatimuksista ja etiikasta lähtien, minkä vuoksi saamelaisten tutkijan on oltava saamelainen tai ainakin tutkimusryhmässä on oltava saamelaisjäseniä. Tämä on hyvin radikaali kanta, joka rakentaa ennakkoluuloja saamelaisten ja muiden välille eikä ota huomioon kulttuurientutkimuksessa viime vuosikymmeninä tiedon keräämisestä ja esittämisestä käytyjä keskusteluja kokonaisuudessaan.

Saamelaisasioita ajavien ihmisten esittely laajenee lukuisten viittausten siivittämänä koko saamelaispolitiikkaa koskevaksi tietoverkoksi, jonka tuottamisesta Irja Seurujärvi-Kari näyttää vastanneen lähes yksin. Etnisen heräämisen historia tulee kuvatuksi monesta näkökulmasta, kun sitä ei valota ainoastaan Altan konflikti vaan myös monet henkilöt ja lukuisat kansalaisjärjestöt. Saamelaisia pidetään maailman järjestäytyneimpänä alkuperäiskansana, mikä heijastuu myös kirjassa esille tulevaan saamelaisten merkittävään asemaan kansainvälisessä alkuperäiskansaliikkeessä. Erilaisten kansainvälisten elinten ja kansalaisjärjestöjen rinnalla kulkee valtava ja yksityiskohtainen tietokokonaisuus alkuperäiskansoja ja saamelaisia koskevista sopimuksista ja lainsäädännöstä. Tämä ei heijastane ainoastaan saamelaisten järjestyneisyyttä vaan myös sitä, että saamelaisasioita etenkin pohjoismaissa on viime aikoina käsitelty oikeuksien, niiden menettämisten ja saavuttamisten kautta.

Tietosanakirjassa on laajasti esitelty myös kaikki saamelaiskielet ja kielten tutkimukseen liittyvä historia ja terminologia. Esimerkiksi arkeologiset termit tuntuvat tulevan esitellyiksi liian laajasti, mutta kielitieteellinen terminologia sopivassa laajuudessa. Sen sijaan 49 etymologisen artikkelin taustalla olevat valintakriteerit jäivät epäselviksi. Kieleen liittyen on ongelmallista, etteivät kirjan tekijät ole alun perin sopineet, mitä saamen kielistä he käyttävät artikkeleissaan. Näin etenkin perinnettä ja kansanuskoa kuvaavat artikkelit tuntuvat käyttävän milloin minkin kielistä versiota, jonka käyttö perustunee enemmänkin tutkimuskonventioihin kuin tekijöiden sopimuksiin. Sopimukset olisivat selkeyttäneet kirjan kielipolitiikkaa.

Yhteiskuntaa ja kulttuuria sivuavien artikkelien lisäksi teoksessa esitellään myös saamelaisalueen luontoa, ympäristöä sekä sen käyttöä monista eri näkökulmista. Luonnollisesti erityisesti saamelaisten kannalta merkittävät lajit, ilmiöt ja elinkeinot ovat pääosassa. Poronhoito on saanut ja varmasti ansainnutkin upean ja monitahoisen sekä keskustelevan artikkelin, jossa pystytään kritisoimaan myös alkuperäiskansan luonnonkäyttötapoja. Ympäristöaiheisia mutta myös muita kirjan artikkeleita vaivaa valitettavasti pohjoismaakeskeisyys, vaikka yksi kirjan tavoitteista on ollut tuoda esiin usein marginaaliin jääviä itäisiä saamelaisia. Kuolan saamelaisten elämää, kulttuuria ja historiaa esitellään kyllä lukuisissa erityisissä artikkeleissa, jotka ovat myös hyvin ansiokkaita. Mutta ikävän usein muissa artikkeleissa käydään läpi pohjoismaiden saamelaiset Venäjän saamelaisia mainitsematta. Näin on myös saamelaispolitiikkaa ja tutkimushistoriaa koskevissa artikkeleissa: mikseivät esimerkiksi sellaiset merkittävät Kuolan saamelaisten tutkijat kuin Haruzin ja Charnolusskij ole saaneet omia artikkeleitaan, vaan koko 1900-luvun venäläinen saamentutkimus on typistetty yhdeksi tekstiksi (Saami Studies: Russia/USSR)? 


\section{Perinteestä ja kansanuskosta}

Perinteentutkimuksen vinkkelistä ensyklopediassa esitellään monet keskeisimmät teemat ja ilmiöt. Erityisesti esineellistä kulttuuria koskevat artikkelit ilahduttavat, sillä niissä tulee kerrotuksi sekä mennyt että nykypäivä. Saamelaisten kansallispukuja käsittelevä artikkeli on niiin kirjoitettu kuin kuvitettu hyvin, käsityöt (Duodji) esitellään aina nykypäivään asti samoin kuin turkisvaatteet (Skin clothes) tai vaikka ruoan käsittely (Food management).

Aineettoman kulttuurin käsittelyn tapa taas herätti itsessäni monesti kummastusta. Henkisen kulttuurin teemoja esitellään lukuisissa artikkeleissa varsin kattavasti. Folkloristia kyllä hieman ihmetyttää, mihin ovat unohtuneet vielä nykyäänkin eläviä ja äskettäin tutkittujakin kertomusgenrejä, esimerkiksi máinnasta tai muitalusta, koskevat artikkelit. Proosaperinnettä esitellään yleisesti ja lähinnä etic-termien kautta artikkelissa Legends and tales ja erityisemmin ainoastaan inarinsaamelaisten kertovaa perinnettä käsittelevä osiossa (Inari Saami Folklore), joka on erittäin hyvä. Joidenkin, vaikkakin folkloristisesti keskeisten osa-alueiden poisjääminen ei kuitenkaan ole mielestäni niin suuri ongelma kuin perinteen ilmiöiden yleinen tulkintakehys. Se ei valitettavasti vastaa enää nykyisiä folkloristiikan keskusteluja, joissa perinnettä halutaan tulkita ihmisten käytössä, käyttämänä ja tulkitsemana kokonaisuutena - emicnäkökulmasta niin kuin ensyklopediassakin on haluttu tehdä. Tämä näkyy ainakin artikkelin kirjoittajien taipumuksena etsiä ehdottomia tai lopullisia tulkintoja kuten seitoja koskevassa artikkelissa tuodaan esille (s. 391) tai kirjoittaa monista perinteen ilmiöistä menneessä aikamuodossa.

Lopulliset tulkinnat ovat usein hämmentäviä juuri historiallis-vertailevan otteensa vuoksi. Ilmiöitä palautetaan skandinaavisiin alkuperiin tai jopa selittämättömään kantauralilaiseen vaiheeseen (esimerkiksi artikkeleissa Pre-Christian gods, Sáiva) sen sijaan, että pohdittaisiin niiden merkityksiä saamelaisten menneessä tai nykyisessä arkipäivässä. Menneessä aikamuodossa kirjoitetaan etenkin kansanuskoa koskevissa artikkeleissa, mikä on osin täysin oikeutettuakin. Ilmeisesti juuri mennyt aikamuoto oikeuttaa myös sen, että uskomusperinteistä kirjoitetaan kollaasinomaisesti, eri aikojen ja paikkojen uskonnollisia käytäntöjä ja diskursseja kuvaavia lähteitä yhdistellen ja toisiinsa mukauttaen. Näin esimerkiksi kertomusperinteen hahmoja Njávešeatnea ja Áb̆̌́šeatnea koskeva artikkeli luo ehjää kuvaa tai kertomusta, kun todellisuudessa kyseessä on kaikkialla saamelaisten keskuudessa elävä tai elänyt monitahoinen kertomusperinne, jonka merkitykset ovat varmasti vaihdelleet ajan ja paikan mukaan. Kertomusperinteen liiasta etäisyydestä kertoo myös se, että esimerkiksi tarinoita eläimeksi muuttumisesta (Animal metamorphoses) on tulkittu sananmukaisesti niin, että karhuksi ja sudeksi muuttumista pidettiin aikoinaan tavanomaisena.

Saamelaisten kristillistymistä on ensyklopediassa kuvattu monitahoisesti. Kristinuskon nähdään yhtäältä tuhoavan perinteistä kulttuuria ja kansanuskoa (lähetystyöntekijät ja papit), toisaalta tuovan jotain uutta ja hedelmällistä saamelaisten pariin (lestadiolaisuus ja siihen liittyvät liikkeet). Tosin seitoja koskevassa artikkelissa on mielestäni liian yksisuuntaisesti tulkittu kuvauksia saamelaisten kirkossa käymisestä. Niiden mukaan saamelaiset ovat jättäneet omat pyhät paikkansa ja alkaneet käydä 


\section{KULTTUURISIA KUVIA SAAMELAISISTA JA SAAMELAISUUDESTA}

kirkoissa mukisematta. Tuskin mikään muutos käy näin yksioikoisesti, ja kristinuskon omaksumista tulisikin tutkia lähemmin saamelaisten omista näkökulmista. Monia kirkkokuvauksia voisi tulkita myös siltä kannalta, miten saamelaiset ovat sisällyttäneet kristillisiä käytäntöjä omiin käsityksiinsä, sillä juuri sitä kautta muutoksen on pitänyt lähteä liikkeelle. Perinteentutkija jääkin kaipaaman juuri tämänlaisia ajallisesti ja paikallisesti rajattuja ja yksityiskohtaisia esittelyjä.

FM Karina Lukin on folkloristiikan jatko-opiskelija Helsingin yliopistossa. 